\title{
Indoor Air Quality Assessment of Latin America's First Passivhaus Home
}

\author{
Alejandro Moreno-Rangel ${ }^{1,2, *} \mathbb{C}$, Filbert Musau ${ }^{1}$, Tim Sharpe ${ }^{1,3}$ TiD $^{-}$and Gráinne McGill ${ }^{1,3}$ \\ 1 Mackintosh Environmental Architecture Research Unit, The Glasgow School of Art, Glasgow G3 6RQ, UK; \\ f.musau@gsa.ac.uk (F.M.); tim.sharpe@strath.ac.uk (T.S.); grainne.mcgill@strath.ac.uk (G.M.) \\ 2 Lancaster Institute of the Contemporary Arts, Lancaster University, Lancaster LA1 4YW, UK \\ 3 Department of Architecture, University of Strathclyde, Glasgow G1 1XJ, UK \\ * Correspondence: a.morenorangel@lancaster.ac.uk; Tel.: +44-(0)-152-510873
}

Citation: Moreno-Rangel, A.; Musau, F.; Sharpe, T.; McGill, G. Indoor Air Quality Assessment of Latin America's First Passivhaus Home. Atmosphere 2021, 12, 1477. https: / / doi.org/10.3390/ atmos12111477

Academic Editor: Ashok Kumar, Amirul I Khan, Alejandro Moreno Rangel and Michał Piasecki

Received: 4 October 2021

Accepted: 3 November 2021

Published: 8 November 2021

Publisher's Note: MDPI stays neutral with regard to jurisdictional claims in published maps and institutional affiliations.

Copyright: (c) 2021 by the authors. Licensee MDPI, Basel, Switzerland. This article is an open access article distributed under the terms and conditions of the Creative Commons Attribution (CC BY) license (https:// creativecommons.org/licenses/by/ $4.0 /)$.

\begin{abstract}
Sustainable building design, such as the Passivhaus standard, seeks to minimise energy consumption, while improving indoor environmental comfort. Very few studies have studied the indoor air quality (IAQ) in Passivhaus homes outside of Europe. This paper presents the indoor particulate matter $\left(\mathrm{PM}_{2.5}\right)$, carbon dioxide $\left(\mathrm{CO}_{2}\right)$, and total volatile organic compounds (tVOC) measurements of the first residential Passivhaus in Latin America. It compares them to a standard home in Mexico City. Low-cost monitors were installed in the bedroom, living room, and kitchen spaces of both homes, to collect data at five-minute intervals for one year. The physical measurements from each home were also compared to the occupants' IAQ perceptions. The measurements demonstrated that the Passivhaus $\mathrm{CO}_{2}$ and $\mathrm{tVOC}$ annual average levels were $143.8 \mathrm{ppm}$ and $81.47 \mu \mathrm{g} / \mathrm{m}^{3}$ lower than the standard home. The $\mathrm{PM}_{2.5}$ in the Passivhaus was $11.13 \mu \mathrm{g} / \mathrm{m}^{3}$ lower than the standard home and $5.75 \mu \mathrm{g} / \mathrm{m}^{3}$ lower than outdoors. While the results presented here cannot be generalised, the results suggest that Passivhaus dwellings can provide better and healthier indoor air quality in Latin America. Further, large-scale studies should look at the indoor environmental conditions, energy performance, and dwelling design of Passivhaus dwellings in Latin America.
\end{abstract}

Keywords: Passivhaus; indoor air quality (IAQ); Latin America; particulate matter $\left(\mathrm{PM}_{2.5}\right)$; carbon dioxide $\left(\mathrm{CO}_{2}\right)$; total volatile organic compounds (tVOC)

\section{Introduction}

Sustainable building design is in constant evolution; such a process has been emphasised due to climate change issues. Sustainable architecture aims to deliver buildings that balance their ecological impact, and even go further. The construction industry has faced significant challenges, to reduce energy demand while providing better indoor environmental quality [1]. Buildings have reduced heat losses through the building envelope and introduced active and passive techniques to reduce energy use further. However, these changes have been mainly motivated by environmental concerns, energy prices, and an increased demand for housing [2]. Other factors, such as indoor environmental comfort and health, have not been addressed adequately in the past, but have seen increased attention, particularly indoor air quality (IAQ); after the COVID-19 lockdowns [3,4]. Different organisations have developed benchmarking systems and certifications to promote and recognise energy-efficient buildings through different design and construction criteria. Some examples include BREEAM (Building Research Establishment Environmental Assessment), LEED (Leadership in Energy and Environmental Design), and the Passivhaus standard, on which this work is based.

A Passive House, or 'Passivhaus', which is the original German term, is '[... ] a building, for which thermal comfort (ISO 7730) can be achieved solely by post-heating or post-cooling of the fresh air mass, which is required to achieve sufficient indoor air quality conditions-without the need for additional recirculation of air [5]'. Nevertheless, the 
Passivhaus does not have specific criteria for IAQ and relies on the DIN1946 suggested airflow rates to manage ventilation and, hence, the removal of indoor air pollutants. The German standard DIN1946 establishes air flow rates between 0.5 and $1.0 \mathrm{ach}^{-1}$, suggesting that these ventilation rates should be sufficient to avoid $\mathrm{CO}_{2}$ peaks above $1500 \mathrm{ppm}$.

The Passivhaus standard is based on five fundamental concepts: thermal insulation, thermal bridge-reduced design, airtightness, adequate ventilation strategy (usually through mechanical ventilation with heat recovery (MVHR) systems), and the use of Passivhaus windows and doors (for a detailed explanation of the Passivhaus principles see [6]). Additionally, the building must adhere to strict design criteria detailed in the Passive House Planning Package (PHPP, currently version 9) [7]. Although the Passivhaus standard was first developed for cold central European countries, its methodology has been introduced to warmer climates such as those found in Latin America.

Between 1990 and 2005, a few Passivhaus homes were built, mainly in cold climates from European countries. The interest in Passivhaus buildings has expanded outside of Europe. According to the Passivhaus Institute in Latin America (ILAPH), the uptake of the Passivhaus standard in Latin America started in 2010 with a non-residential Passivhaus pilot building in Chile. However, it was not until 2014 that the first dwelling received certification, in Mexico. Since then, other dwellings have achieved certification, but have only been subject to scientific scrutiny through virtual modelling, mainly through the PHPP; until now. These studies show evidence of the thermal comfort [8], energy [9,10], economic [11,12], and environmental [13] performance, as well as the feasibility [14,15] of Passivhaus buildings in Latin America. Their measured performance evaluation is limited to thermal comfort [16], energy [17], or limited to short ( $\leq 3$ months) term studies [18]. Passivhaus dwellings have attracted scientific scrutiny of their energy performance [19-21], thermal comfort [22-25], and IAQ [21,26-29] in other parts of the world.

Indoor air quality (IAQ) refers to the indoor concentration of air pollutants that can harm human wellbeing [30]. Nevertheless, what constitutes safe or adequate levels is a current debate. Some authors claim that this should be a complete absence of air contaminants [31]. In contrast, others suggest that low concentrations, which are not detrimental to public health, are acceptable [32]. In 2000, the World Health Organisation (WHO) recognised healthy air as a human right [33] and published guidelines for safe thresholds of different indoor air pollutants [34]. The Passivhaus standard does not explicitly address off-gassing from building materials or other air pollution issues in buildings. Instead, it relies on ventilation rates $\left(30 \mathrm{~m}^{3} / \mathrm{h}\right.$ per person or $\left.0.3 \mathrm{ach} / \mathrm{h}\right)$ to achieve acceptable levels. Hence, IAQ in Passivhaus dwellings is a topic that has captivated the interest of researchers.

Several studies [35-39] suggest that Passivhaus dwellings have the means to achieve acceptable IAQ, even when compared to other non-Passivhaus homes [40-44]. However, very few have compared the measured IAQ to the occupant's IAQ perception $[29,45,46]$. Other studies show conflicting results, suggesting that the IAQ in a Passivhaus may not be adequate [47-49]. Some of the Passivhaus principles, airtightness and ventilation, directly impact the IAQ in homes. For instance, the required levels of airtightness $(\leq 0.6 \mathrm{~h}-1 @ 50 \mathrm{~Pa})$ in Passivhaus dwellings help avoid condensation and conserve energy by reducing air infiltration. However, it is unclear whether an airtight building envelope has clear IAQ benefits [39,50] or not [51]. Nevertheless, occupants' satisfaction with IAQ and indoor humidity is better than those living in non-Passivhaus dwellings [44].

A previous study [26] suggested further work on long-term studies, to understand the IAQ performance of Passivhaus worldwide, in climates different from those found in central European countries. To the authors' knowledge, this work is the first to measure and evaluate the long-term IAQ performance of a Passivhaus dwelling in Latin America. Indoor air quality parameters were measured using low-cost monitors with remote access capabilities. Additionally, the occupants' perception of IAQ was assessed and compared to the physical measurements. Finally, this paper discusses further work to support the development of the Passivhaus standard in Latin American countries. This work focuses on IAQ, as the thermal performance of this Passivhaus dwelling is discussed elsewhere [16]. 


\section{Method}

This study presents results from a monitoring campaign of a certified Passivhaus dwelling, and another built with the standard building practices in Mexico City. This campaign took place between 1 June 2016 and 31 May 2017. Locations with an Oceanic Subtropical Highland Climate $(\mathrm{Cwb})$, such as Mexico City, are characterised by warm and wet summers, with dry and warmer winters [52]. Foobot was used to monitor air temperature $\left(-40-125{ }^{\circ} \mathrm{C} ; \pm 0.4{ }^{\circ} \mathrm{C}\right)$, relative humidity $(0-100 \% \mathrm{RH} ; \pm 4 \% \mathrm{RH})$, particulate matter $2.5 \mu \mathrm{m}\left(\mathrm{PM}_{2.5}\right)\left(0-1300 \mu \mathrm{g} / \mathrm{m}^{3} ; \pm 4 \mu \mathrm{g} / \mathrm{m}^{3}\right.$ or $\left.\pm 20 \%\right)$, and total volatile organic compounds (tVOC) $\left(125-1000 \mu \mathrm{g} / \mathrm{m}^{3} ; \pm 1 \mu \mathrm{g} / \mathrm{m}^{3}\right.$ or $\left.\pm 10 \%\right)$. As the Foobot does not have a dedicated carbon dioxide $\left(\mathrm{CO}_{2}\right)$ sensor, a Netatmo $(0-5000 \mathrm{ppm} ; \pm 50 \mathrm{ppm}$ or $5 \%)$ was used for these measurements. The accuracy of both the Foobot [53] and Netatmo [54] monitors has been tested and validated for carrying out long-term IAQ monitoring. The calibration equations used in this study are described in greater detail in a previous study from our research group [53].

We adopted a novel monitoring methodology for this research, avoiding researcher visits to the homes. Instead, the participants were asked to install the monitors and asked for the surveys online, as described in [55]. They received a pack with information on how to operate the monitors and where to place them. These monitors were used as they could be deployed remotely, with remote data collection, and were acceptable to the building owners who installed them. The Foobot monitors were installed in the living room, kitchen, and bedroom, while the Netatmos were only placed in the living room and bedroom. The sensors collected data continuously at five-minute intervals, for one year. As this was a long-term study, using these low-cost monitors for outdoor monitoring would have been difficult and added challenges for the building occupants to install a different set of sensors (i.e., outdoor air quality, doors, windows, and movement sensors).Hence, outdoor parameters were collected from the 'Hospital General de México (HGM)' station ( $<1 \mathrm{~km}$ from the homes) of Mexico City's official local atmospheric monitoring program (http:/ / aire.cdmx.gob.mx/ (accessed on 16 August 2021), see location in Figure 1).

Occupant perceptions of IAQ were collected through a certified indoor environmental survey [56], which was adapted to an online format. Building occupants were asked to complete the surveys after the end of the monitoring phase, considering their experiences throughout the previous year. This survey examined their perception of air freshness, moisture, movement, the outdoors, and their overall satisfaction with the air quality. The survey was based on seven-option rating scales, was unipolar and bipolar, and assessed following the survey guidelines (see [56] for detailed instructions). As this was a long-term study, it was also not viable to ask the participants to keep a detailed diary of their activities, therefore, participants were asked to provide the general weekly occupancy pattern of the dwelling and window opening patterns on which the analysis is based. 


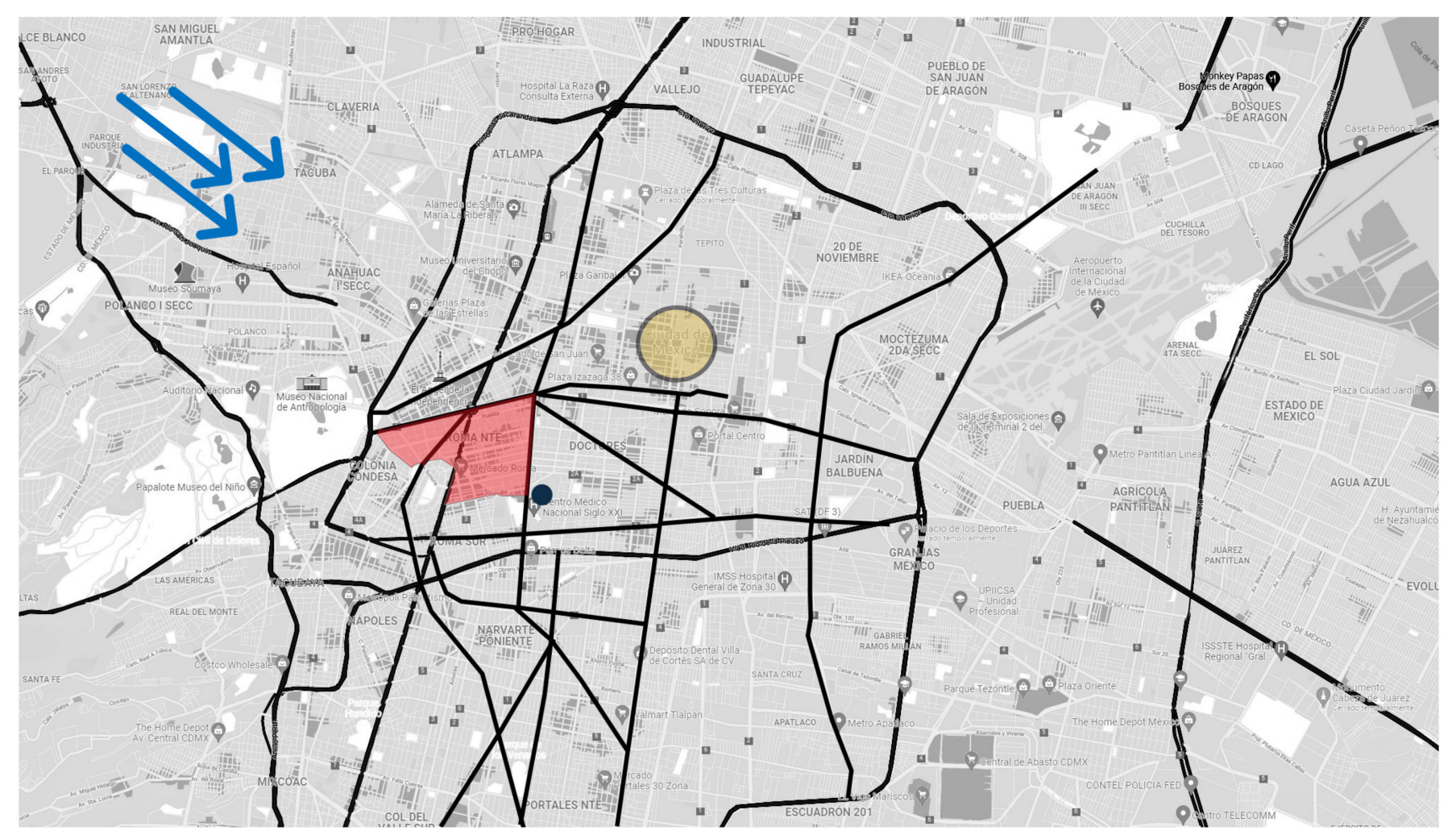

Figure 1. Location of the homes in Mexico City. The red highlighted area shows the Roma Norte. The navy dot represents the location of the monitoring station. The yellow circle highlights the area of the city centre. The blue arrows the main wind direction. Source: Authors, based on Google map image.

\subsection{Indoor Air Quality Criteria}

Standard protocols for measuring the IAQ in homes are limited. Usually, such protocols are designed for general IAQ monitoring (i.e., CIBSEKS17, ASTM D6245-12, and the BS EN ISO 16000-1:2006) and are adapted for residential studies. In this study, we followed the recommendations from BS EN ISO 16000-1:2006 and used the following thresholds:

- $\quad \mathrm{PM}_{2.5}: 25 \mu \mathrm{g} / \mathrm{m}^{3}$ at $24 \mathrm{~h}$ mean and annual mean of $10 \mu \mathrm{g} / \mathrm{m}^{3}$, as defined by WHO [33].

- $\quad t V O C: 300 \mu \mathrm{g} / \mathrm{m}^{3}$ over $8 \mathrm{~h}$ mean, as defined by the WHO [33].

- $\quad \mathrm{CO}_{2}: 1000 \mathrm{ppm}$, as defined by IDA3 (moderate IAQ based on the EN 13779:2007 [57])

- Relative humidity: $40-60 \% \mathrm{RH}$ (ideal) and 30-70\%RH (extended) as defined by CIBSE [58].

\subsection{Household Characteristics}

The dwellings are located within the Roma Norte neighbourhood in the west of Mexico City's historic centre, within less than $500 \mathrm{~m}$ of each other (Figure 1). The Roma Norte encompasses diverse building uses residential, restaurants, bars, clubs, shops, churches, and galleries. The borders of the neighbourhood are three principal avenues, which have dense and constant traffic, this is in combination with the winds in the city, which bring the surrounding pollution of the industrial zones to the central neighbourhoods.

Both dwellings have the same orientation, north to south, facing the predominant winds (north-west). While the homes are different in size and floor plan layout (Figure 2a,b), it was deemed adequate to compare them, as the standard home represents the most common typology [59]. Both dwellings have similar occupancy and multipurpose rooms (kitchen, living room, and dining area). Two adults and one child occupied each of the dwellings. Table 1 describes the frequency of window opening and the occupancy patterns, as depicted in the occupancy diaries. Table 2 shows a summary of the building characteristics and construction details. 


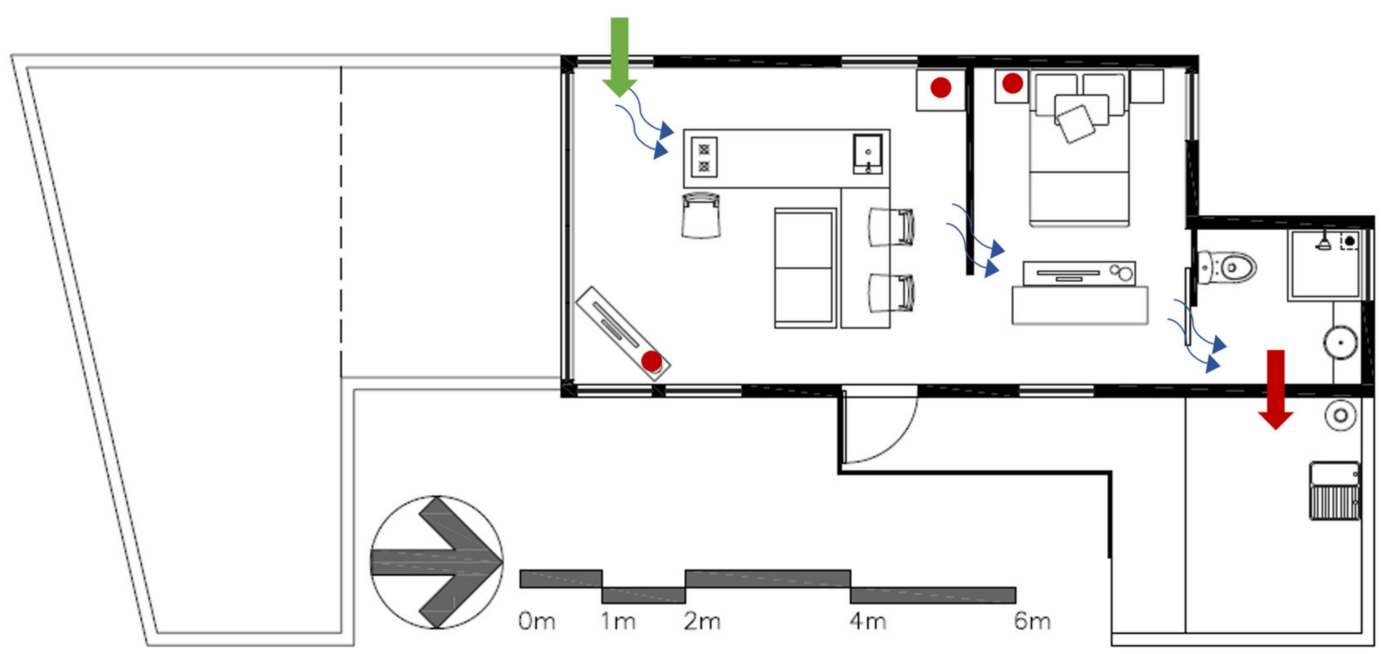

(a)

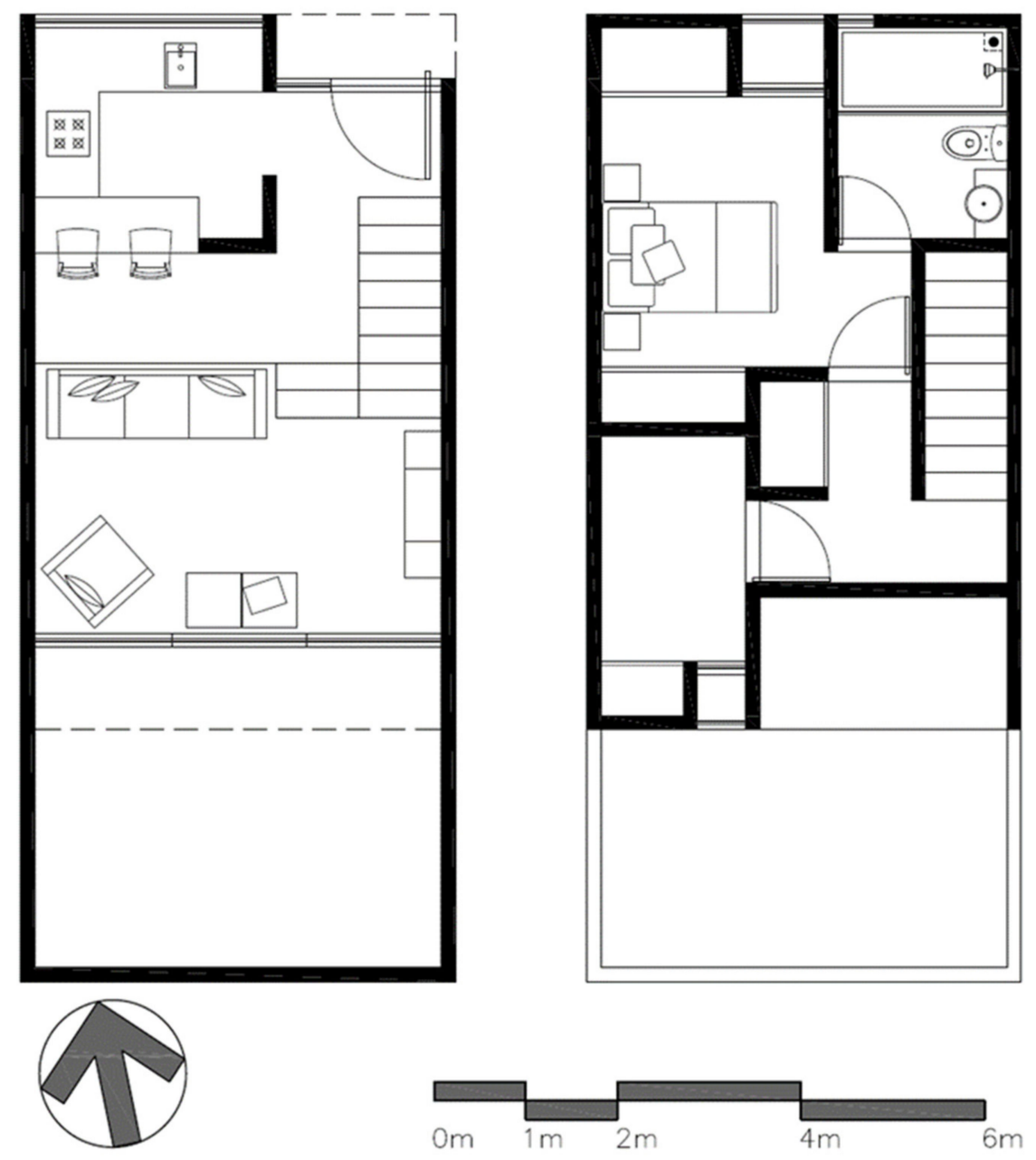

(b)

Figure 2. (a) Passivhaus dwelling floor plan. The red dots indicate the placement of the sensors. The blue arrows indicate the ventilation flow. The green and red arrows represent the inlet openings and extraction fan, respectively. Source: authors. (b) Standard dwelling floor plan. Source: Authors. 
Table 1. Household characteristics. Source: Authors.

\begin{tabular}{ccc}
\hline Household Characteristic & Passivhaus Dwelling & Standard Dwelling \\
\hline Household occupancy & 2 Adults, 1 child $(>16)$. & 2 Adults, 1 child $(>16)$. \\
Age range (years) & $40-50,<16$ & $40-50,50-60,<16$ \\
Smoking & No, only outdoors & No, only outdoors \\
Bedroom & Occupancy Pattern (Daily) & \\
Kitchen & $00: 00-06: 30 ; 22: 30-24: 00$ & $00: 00-06: 30 ; 22: 30-24: 00$ \\
& $07: 30-09: 00 ; 14: 00-16: 00 ;$ & $07: 30-09: 00 ; 11: 00-16: 00 ;$ \\
Living room & $20: 30-21: 30$ & $20: 30-21: 30$ \\
& $09: 00-09: 30 ; 14: 00-16: 00 ;$ & $09: 00-09: 30 ; 11: 00-16: 00 ;$ \\
Morning & $21: 30-22: 30$ & $21: 30-22: 30$ \\
Afternoon & Frequency of Window Opening & \\
Evening & Rarely & Constantly \\
Night & Occasionally & Regularly \\
\hline & Regularly & Occasionally \\
& Constantly & Rarely \\
\hline
\end{tabular}

Table 2. Main building characteristics of the Passivhaus and Standard Dwellings. Source: Authors.

\begin{tabular}{|c|c|c|}
\hline Building Characteristic & Passivhaus Dwelling & Standard Dwelling \\
\hline Airtightness $\left(\mathrm{n}_{50}\right)$ & $0.59 \mathrm{~h}^{-1}$ & Not tested \\
\hline Floor area & $42 \mathrm{~m}^{2}$ & $57 \mathrm{~m}^{2}$ \\
\hline Main door & PVC (Passivhaus certified) & Wood (standard) \\
\hline $\mathrm{U}_{\mathrm{g}}$-value (window) & $1.64 \mathrm{~W} /\left(\mathrm{m}^{2} \mathrm{~K}\right)$ & $5.78 \mathrm{~W} /\left(\mathrm{m}^{2} \mathrm{~K}\right)$ \\
\hline U-value (floor slab) & $0.33 \mathrm{~W} /\left(\mathrm{m}^{2} \mathrm{~K}\right)$ & $13.66 \mathrm{~W} /\left(\mathrm{m}^{2} \mathrm{~K}\right)$ \\
\hline U-value (roof) & $0.36 \mathrm{~W} /\left(\mathrm{m}^{2} \mathrm{~K}\right)$ & $13.66 \mathrm{~W} /\left(\mathrm{m}^{2} \mathrm{~K}\right)$ \\
\hline U-value (wall) & $0.37 \mathrm{~W} /\left(\mathrm{m}^{2} \mathrm{~K}\right)$ & $1.18 \mathrm{~W} /\left(\mathrm{m}^{2} \mathrm{~K}\right)$ \\
\hline Ventilation & $\begin{array}{l}\text { Mechanical extraction and cross } \\
\text { natural ventilation. } \\
\text { Due to the mild climate, no MVHR was needed. } \\
\text { An extraction fan ran intermittently to provide } \\
42 \mathrm{~m}^{3} / \mathrm{h} \text { as calculated by the PHPP calculations; } \\
\text { no kitchen hood. }\end{array}$ & $\begin{array}{c}\text { Natural (cross and stack). Calculated } \\
\text { ventilation }\left(89.6 \mathrm{~m}^{3} / \mathrm{h}\right) \text { depending on the } \\
\text { outdoor conditions Kitchen hood fans with } \\
\text { no extract. }\end{array}$ \\
\hline Window type & $\begin{array}{l}\text { Double-glazing } 6 \mathrm{~mm} / 12 \mathrm{~mm} \text { air, } 4 \mathrm{~mm} \\
\text { low-e-clear-claro (Passivhaus certified) }\end{array}$ & Single glazing 3 mm (Standard) \\
\hline \multirow[t]{2}{*}{ Building Standard } & Passivhaus (certified) & Mexico City's Standard Building Regulation \\
\hline & \multicolumn{2}{|c|}{$\begin{array}{l}\text { In warmer climates, the Passivhaus ventilation strategy may differ from the one } \\
\text { recommended in European countries. Rather than using mechanical ventilation with a heat } \\
\text { recovery (MVHR) system, the ventilation can rely on mechanical and natural ventilation } \\
\text { (hybrid). This Passivhaus dwelling used mechanical extraction ventilation, in the toilet, } \\
\text { and three openings with a total of } 0.05 \mathrm{~m}^{2} \text {, in the living room, at the other end of the house } \\
\text { (see green and red arrows in Figure } 2 \mathrm{a} \text { ). These inlet openings were initially fitted with an F7 } \\
\text { filter-for fine dust and } \mathrm{PM}_{1-10} \text {. As the filters were difficult to find on the Mexican market at } \\
\text { the time, they were removed as they could not be periodically changed. Therefore, during } \\
\text { this study, no filters were present. Before the monitoring phase, the ventilation system was } \\
\text { recommissioned to ensure that the air flows were as stated in the PHPP }\left(42 \mathrm{~m}^{3} / \mathrm{h} \text { ). }\right.\end{array}$} \\
\hline
\end{tabular}

\section{Results}

\subsection{Passivhaus Ventilation}

A Passivhaus design for hybrid ventilation must ensure that the required ventilation is still met in the most unfavourable conditions, when windows are closed, and natural 
ventilation is restricted. Therefore, the Passivhaus still needs to provide the ventilation required by the Passivhaus calculation through mechanical means. The air flows in the house were tested and adapted accordingly to the PHPP calculation $\left(42 \mathrm{~m}^{3} / \mathrm{h}\right)$. The extraction fan claimed to have a capacity of $95 \mathrm{~m}^{3} / \mathrm{h}$. However, this was reduced to $74.30 \mathrm{~m}^{3} / \mathrm{h}$ after being installed. Nonetheless, this was still higher than the $42 \mathrm{~m}^{3} / \mathrm{h}$ required by the PHPP. The difference was compensated using a timer that regulated the fan operation at $34 \mathrm{~min}$ per hour and allowed manual activation/deactivation.

The $\mathrm{CO}_{2}$ levels were used as a ventilation metric [60] $\left(\mathrm{CO}_{2}\right.$ levels are examined in detail in the next section). The $\mathrm{CO}_{2}$ concentrations in the room were modelled using Equation (1).

$$
c=(q \div n V)\left[1-\left(e^{n t}\right)\right]+\left(c_{0}-c_{i}\right)\left(1 \div e^{n t}\right)+c_{i}
$$

Equation (1). Model for $\mathrm{CO}_{2}$ Concentrations in Rooms with People. Source: [61]. where

$c=$ carbon dioxide concentration in the room $\left(\mathrm{m}^{3} / \mathrm{m}^{3}\right)$

$q=$ carbon dioxide supplied to the room $\left(\mathrm{m}^{3} / \mathrm{h}\right)$

$V=$ volume of the room $\left(\mathrm{m}^{3}\right)$

$e=$ the constant 2.718

$n=$ air changes per hour $(1 / \mathrm{h})$

$t=$ time (hour, h)

$c_{i}=$ carbon dioxide concentration in the inlet ventilation air $\left(\mathrm{m}^{3} / \mathrm{m}^{3}\right)$

$c_{0}=$ carbon dioxide concentration in the room at start, $\mathrm{t}=0\left(\mathrm{~m}^{3} / \mathrm{m}^{3}\right)$

Figure 3 shows the measured $\mathrm{CO}_{2}$ levels (continuous blue line) on 26 March 2017. The calibration model (orange short dashed line) was produced using the real occupancy and ventilation patterns (Density: two persons; activity: sleeping; time interval: 5 min; $\mathrm{CO}_{2}$ emissions per person: $0.015 \mathrm{~m}^{3} / \mathrm{h}$; ventilation rates (calibration model): each hour from 0:00-0:15 at 0.001 ach, 0:15-0:30 at 0.9789 ach $\left(74.3 \mathrm{~m}^{3} / \mathrm{h}\right), 0: 30-0: 40$ at 0.001 ach, and 0:45-1:00 at 0.9789 ach $\left(74.3 \mathrm{~m}^{3} / \mathrm{h}\right)$; room volume: $75.9 \mathrm{~m}^{3}$; and outdoor $\mathrm{CO}_{2}: 500 \mathrm{ppm}$ ) assuming an outdoor level of 500 ppm, as recommended on the EN 13779:2007 [62]. Another model (blue dash-dot-dash line) evaluated the same condition but changed the extraction to a continuous rate of $42 \mathrm{~m}^{3} / \mathrm{h}$, as suggested by the PHPP calculations (Density: two persons; activity: sleeping; time interval: $5 \mathrm{~min} ; \mathrm{CO}_{2}$ emissions per person: $0.015 \mathrm{~m}^{3} / \mathrm{h}$; ventilation rates (continuous flow): $42 \mathrm{~m}^{3} / \mathrm{h}$; room volume: $75.9 \mathrm{~m}^{3}$; and ambient $\mathrm{CO}_{2}: 500 \mathrm{ppm}$ ). Finally, the last model (Density: two persons; activity: sleeping; time interval: $5 \mathrm{~min} ; \mathrm{CO}_{2}$ emissions per person: $0.015 \mathrm{~m}^{3} / \mathrm{h}$; ventilation rates (continuous flow): $74.3 \mathrm{~m}^{3} / \mathrm{h}$; room volume: $75.9 \mathrm{~m}^{3}$; and ambient $\mathrm{CO}_{2}: 500 \mathrm{ppm}$ ) (red long dashed line) evaluated with the total capacity of the installed fan $\left(74.3 \mathrm{~m}^{3} / \mathrm{h}\right)$. The effect can be observed in Figure 4 . 


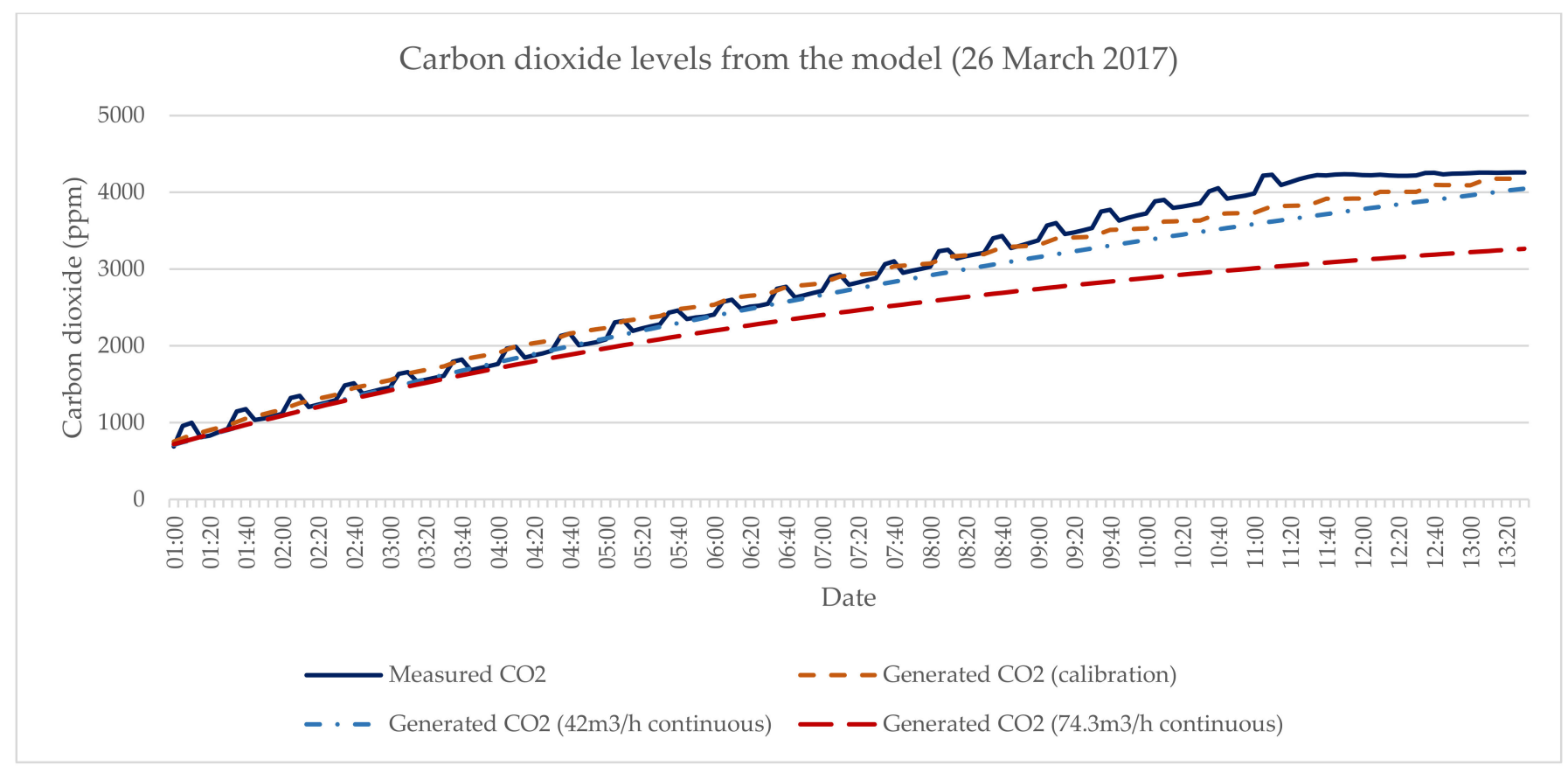

Figure 3. Measured and modelled overnight $\mathrm{CO}_{2}$ levels. Source: Authors.

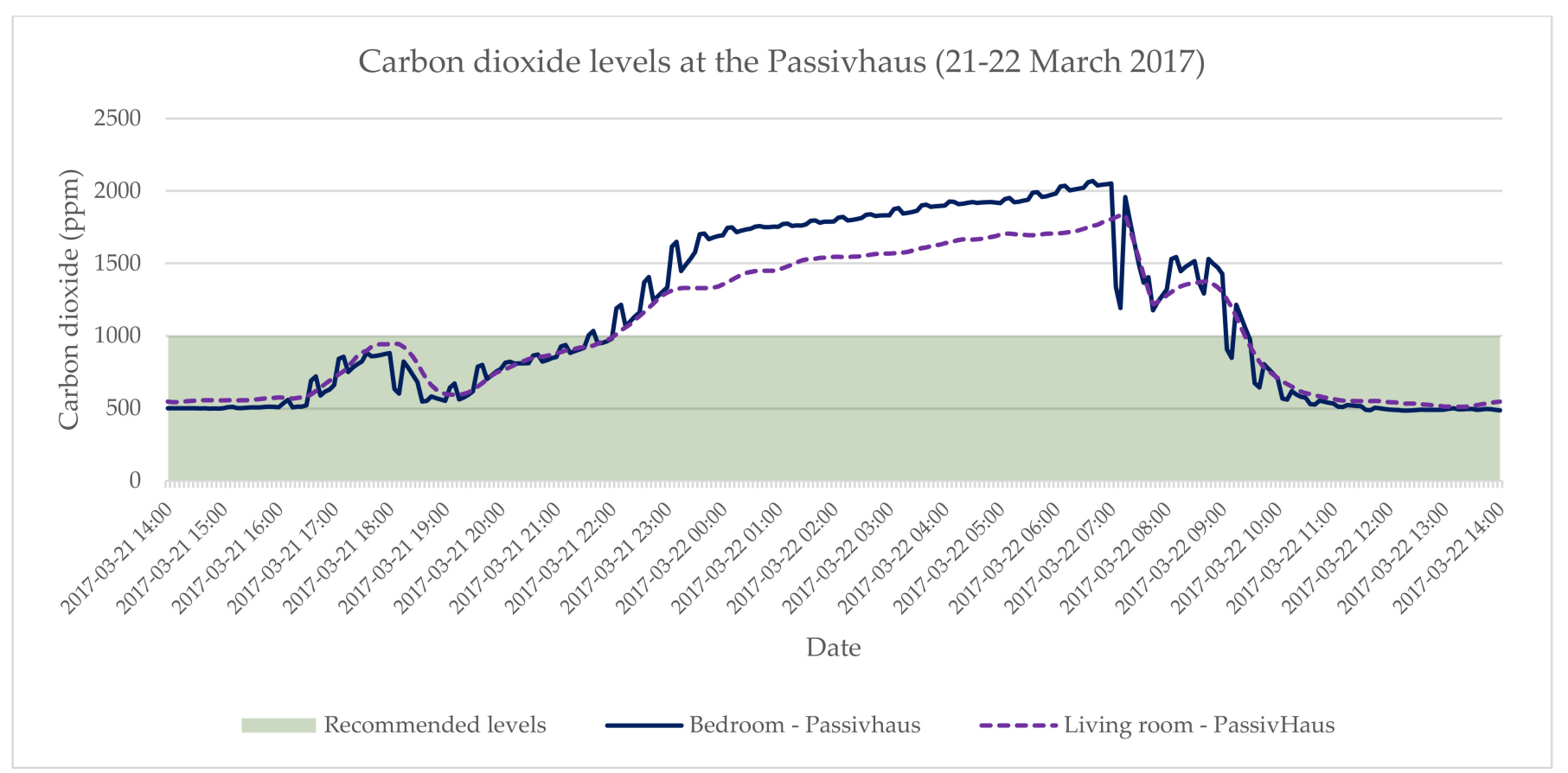

Figure 4. Monitored $\mathrm{CO}_{2}$ levels in Mexico's Passivhaus (21-22 March 2017). Source: Authors.

\subsection{Carbon Dioxide Levels}

The $\mathrm{CO}_{2}$ levels in both monitored spaces, the living room and bedroom, exceeded the recommended $1000 \mathrm{ppm}$ throughout the year. The results showed that the highest levels peaks were during the colder months, when one would expect the windows to remain closed. Nonetheless, the monthly mean levels in both spaces remained below the recommended levels (Figure 5). The overall $\mathrm{CO}_{2}$ levels in the Passivhaus were better compared to those in the standard dwelling. They remained below the recommended $1000 \mathrm{ppm}$ for $85.9 \%$ of the year in the bedroom and $90.1 \%$ in the living room in the Passivhaus. In 
contrast, the standard dwelling bedroom $\mathrm{CO}_{2}$ levels were above $1000 \mathrm{ppm}$ for $42.9 \%$ of the time and $97.5 \%$ in the living room. The $\mathrm{CO}_{2}$ levels of the bedroom of the standard home were of particular concern, particularly at night. A potential explanation could be the differences in the ventilation regulation in the Mexican building regulations, and the fact that windows remained closed during the night due to security concerns. Monthly $\mathrm{CO}_{2}$ levels and a statistical analysis can be found in the Supplementary Table S1.

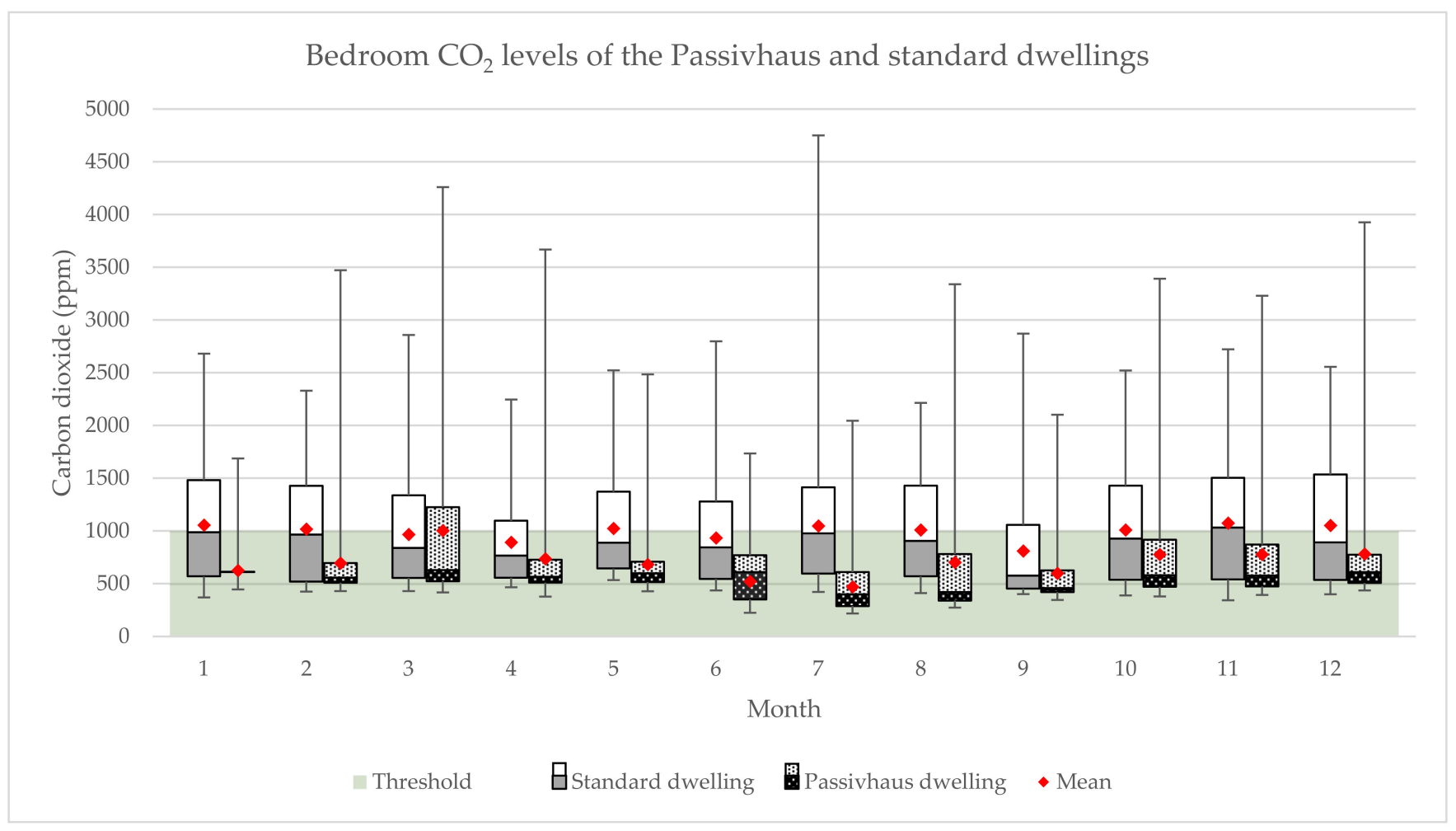

Figure 5. Bedroom annual $\mathrm{CO}_{2}$ levels in the Passivhaus and Standard dwellings. Source: Authors.

\subsection{Particulate Matter $2.5 \mu \mathrm{m}$}

The recommended $\mathrm{PM}_{2.5}$ thresholds of $10 \mu \mathrm{g} / \mathrm{m}^{3}$ and $25 \mu \mathrm{g} / \mathrm{m}^{3}$ were exceeded outdoors and in both dwellings (Figure 6). The measured $\mathrm{PM}_{2.5}$ levels outdoors and in both dwellings are shown in Table 3. In comparison, previous studies found that the mean indoor $\mathrm{PM}_{2.5}$ concentrations ranged between $28.9 \mu \mathrm{g} / \mathrm{m}^{3}$ [63] and $35.1 \mu \mathrm{g} / \mathrm{m}^{3}$ [64]. These levels were significantly higher than those in the Passivhaus dwelling.

The $\mathrm{PM}_{2.5}$ levels in the Passivhaus $\left(r_{s}=0.539-0.587,(p<0.001)\right)$ and the standard $\left(r_{s}=0.539-0.611,(p<0.001)\right)$ dwellings were statistically similar to that outdoors, which is similar to another study where this relationship was significant at $r_{s}=056,(p<0.001)$ [65] (see Section 3.3.1.). Nonetheless, further examination revealed that indoor $\mathrm{PM}_{2.5}$ levels were also affected by indoor behaviours and ventilation strategies. For instance, cooking originated significant pollution peaks, rapidly dissipated in the standard home (Figure S1) due to higher ventilation rates, compared to the Passivhaus dwelling (Figure S2), where the pollution peaks took longer to dissipate. However, once the pollution peaks dissipated, indoor $\mathrm{PM}_{2.5}$ levels remained lower in the Passivhaus dwelling than in the standard home. Monthly $\mathrm{PM}_{2.5}$ levels and a statistical analysis can be found in Supplementary Table S2. 


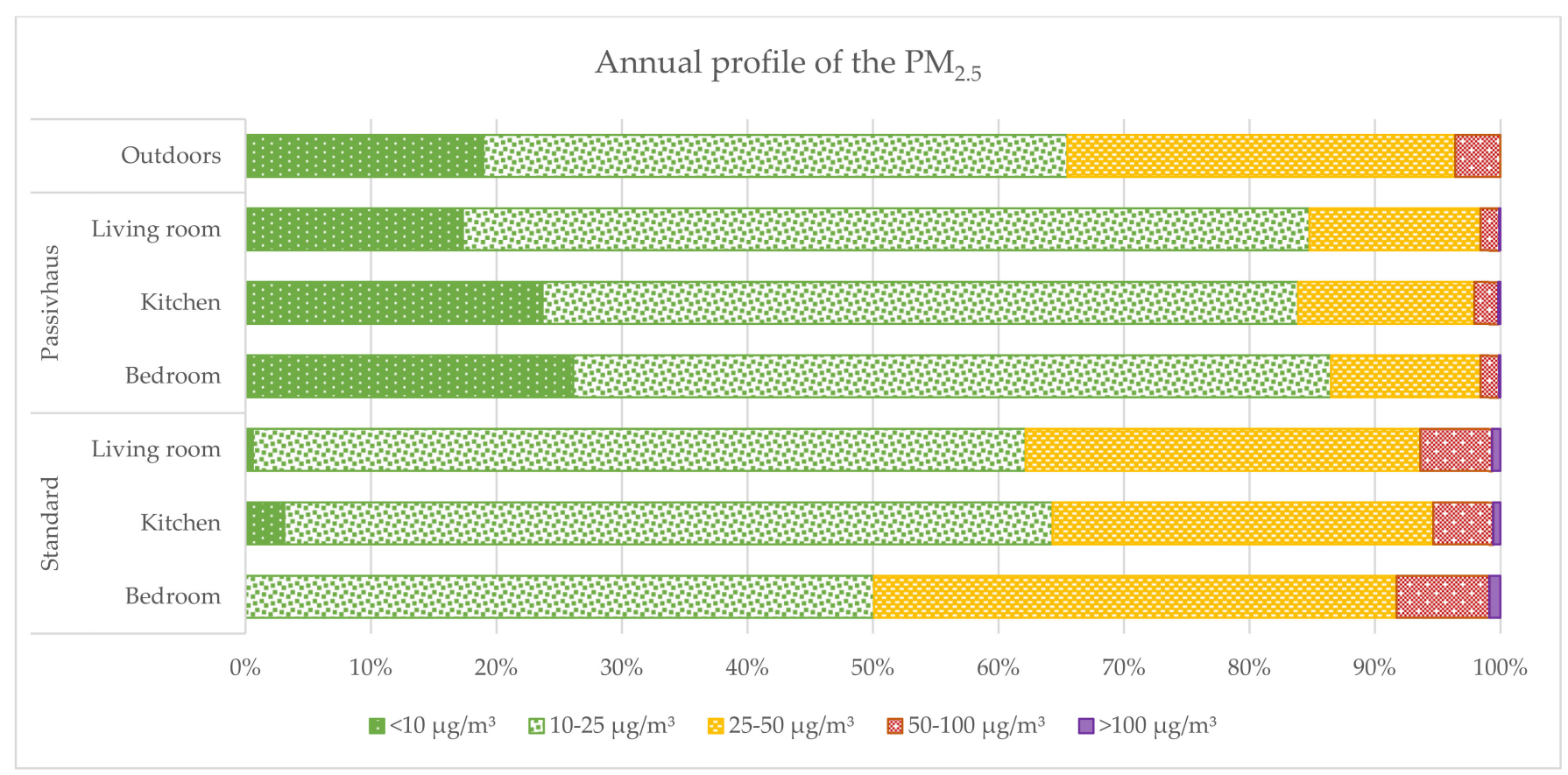

Figure 6. Annual $\mathrm{PM}_{2.5}$ profile in the Passivhaus and standard dwellings. Source: Authors.

Table 3. Annual $\mathrm{PM}_{2.5}$ means compared to the recommended thresholds. Source: Authors.

\begin{tabular}{|c|c|c|c|c|c|c|}
\hline & & $\begin{array}{c}\text { Annual Mean } \\
\left(\mu \mathrm{g} / \mathrm{m}^{3}\right)\end{array}$ & $\begin{array}{l}\text { Standard } \\
\text { Deviation }\end{array}$ & $\begin{array}{c}\% \text { of Time } \\
\text { above } \\
10 \mu \mathrm{g} / \mathrm{m}^{3}\end{array}$ & $\begin{array}{c}\% \text { of Time } \\
\text { above } \\
25 \mu \mathrm{g} / \mathrm{m}^{3}\end{array}$ & $\begin{array}{c}\text { Number of } \\
\text { Days above } \\
25 \mu \mathrm{g} / \mathrm{m}^{3}\end{array}$ \\
\hline \multirow{3}{*}{ Passivhaus } & Bedroom & 15.8 & 10.9 & $73.8 \%$ & $10.7 \%$ & 40 \\
\hline & Living room & 16.9 & 10.5 & $82.7 \%$ & $12.1 \%$ & 44 \\
\hline & Kitchen & 17.2 & 12.0 & $76.3 \%$ & $13.7 \%$ & 50 \\
\hline \multirow{3}{*}{ Standard home } & Bedroom & 29.4 & 18.8 & $100.0 \%$ & $66.0 \%$ & 241 \\
\hline & Living room & 27.8 & 17.1 & $99.4 \%$ & $52.6 \%$ & 173 \\
\hline & Kitchen & 26.1 & 16.9 & $96.9 \%$ & $47.4 \%$ & 192 \\
\hline \multicolumn{2}{|c|}{ Outdoors } & 22.4 & 13.3 & $81.1 \%$ & $35.3 \%$ & 129 \\
\hline
\end{tabular}

\subsubsection{Indoor-Outdoor $\mathrm{PM}_{2.5}$ Levels}

A previous study that looked at indoor and outdoor $\mathrm{PM}_{2.5}$ concentrations in Mexico City found that they were statically similar at $r_{s}=0.56(p<0.001)$, regardless of the season [64]. In this study, we found similar relationships in both dwellings. The Passivhaus indoor-outdoor correlation was significant at $r_{s}=0.539-0.587(p<0.001)$ and in the standard home at $r_{s}=0.539-0.611(p<0.001)$. Although indoor-outdoor $\mathrm{PM}_{2.5}$ levels were significantly correlated, there were some differences between the indoor-outdoor levels measured.

$\mathrm{PM}_{2.5}$ levels in the Passivhaus dwelling were between $5.22 \mu \mathrm{g} / \mathrm{m}^{3}$ to $6.54 \mu \mathrm{g} / \mathrm{m}^{3}$ below outdoor levels and those in the standard home were between $3.65 \mu \mathrm{g} / \mathrm{m}^{3}$ and $7.04 \mu \mathrm{g} / \mathrm{m}^{3}$ above those outdoors as shown in Table 4. Hence, the results in this study suggest that these differences could be related to building related issues or differences in the building occupants' behaviour. Outdoor $\mathrm{PM}_{2.5}$ levels are described in Table S2.

Occupant behaviour, particularly cooking, window opening, and the use of sprays, have an important role in the $\mathrm{PM}_{2.5}$ profiles in homes. Therefore, the impact of cooking and window opening on $\mathrm{PM}_{2.5}$ was analysed in both homes. For instance, cooking fumes produced higher peak levels of $\mathrm{PM}_{2.5}$ as pollution continued to accumulated (being slowly dissipated/driven outdoors). $\mathrm{PM}_{2.5}$ levels were observed to rise in the kitchen during 
cooking. However, the particles travelled to the adjacent rooms, where $\mathrm{PM}_{2.5}$ levels started rising minutes after (Figures S1 and S2).

Table 4. Monthly indoor-outdoor differences of the $\mathrm{PM}_{2.5}$ levels. Source: Authors.

\begin{tabular}{|c|c|c|c|c|c|c|c|c|c|c|c|c|c|c|}
\hline & Month & Jan & Feb & Mar & Apr & May & Jun & Jul & Aug & Sep & Oct & Nov & Dec & Annual \\
\hline \multirow{3}{*}{$\begin{array}{l}\text { Standard } \\
\text { home }\end{array}$} & Bedroom & 2.42 & 5.4 & 3.2 & 0.4 & 9.7 & 4.6 & 5.8 & 12.9 & 9.7 & 11.9 & 11.2 & 7.1 & 7.0 \\
\hline & \multirow{2}{*}{$\begin{array}{l}\text { Kitchen } \\
\text { Living } \\
\text { room }\end{array}$} & -0.92 & 1.2 & -0.7 & 0.7 & 2.3 & 2.0 & 0.3 & 4.0 & 10.9 & 11.3 & 9.6 & 3.2 & 3.7 \\
\hline & & 1.81 & 1.6 & 5.6 & -2.6 & 0.3 & 2.7 & 4.2 & 9.7 & 12.6 & 13.7 & 13.0 & 2.4 & 5.4 \\
\hline \multirow{3}{*}{ Passivhaus } & \multirow{3}{*}{$\begin{array}{l}\text { Bedroom } \\
\text { Kitchen } \\
\text { Living } \\
\text { room }\end{array}$} & -13.67 & -9.6 & -6.1 & -8.8 & -9.5 & -7.5 & -7.1 & -4.0 & -4.4 & 1.5 & -1.9 & -7.7 & -6.5 \\
\hline & & -13.49 & -6.8 & -4.9 & -7.3 & -6.2 & -6.5 & -5.9 & -3.0 & -4.4 & -0.0 & 0.8 & -4.9 & -5.2 \\
\hline & & -14.00 & -7.0 & -2.8 & -8.8 & -10.0 & -5.5 & -5.9 & -4.0 & -5.4 & 2.1 & -0.1 & -4.5 & -5.5 \\
\hline
\end{tabular}

\subsection{Total Volatile Organic Compounds}

As part of the study, indoor tVOC levels were measured. However, it was not possible to collect outdoor measurements, as they were not measured by the local air pollution network and the specifications of the low-cost monitors. A 7-month study found that outdoor tVOC levels in Mexico City were $1462 \mu \mathrm{g} / \mathrm{m}^{3}\left( \pm 763 \mu \mathrm{g} / \mathrm{m}^{3}\right)$ in residential neighbourhoods but could peak at up to $5364 \mu \mathrm{g} / \mathrm{m}^{3}$ [66]. Mean indoor tVOC levels ranged between $569 \mu \mathrm{g} / \mathrm{m}^{3}$ to $578 \mu \mathrm{g} / \mathrm{m}^{3}$ in the Passivhaus, while in the standard home they were $587 \mu \mathrm{g} / \mathrm{m}^{3}$ to $786 \mu \mathrm{g} / \mathrm{m}^{3}$, as illustrated in Figure 7 . Peak pollution levels were commonly observed when the occupants reported using personal cleaning products, cooking, and cleaning activities. These activities impacted the most in the early mornings, when windows usually remained closed and the ventilation rates were lower, as evidenced by the $\mathrm{CO}_{2}$ levels. The effect of the lack of ventilation had a significant impact on the dissipating of indoor $\mathrm{tVOC}$ concentrations. Finally, tVOC concentrations were not directly associated with building or furnishing materials. During non-occupied periods, the levels remained relatively low $\left(<300 \mu \mathrm{g} / \mathrm{m}^{3}\right)$. This could be because both dwellings are more than five years, and tVOC off-gassing is usually higher in new ( $<2$ years) materials [67]. Monthly tVOC levels and statistical analyses can be found in Supplementary Table S3.

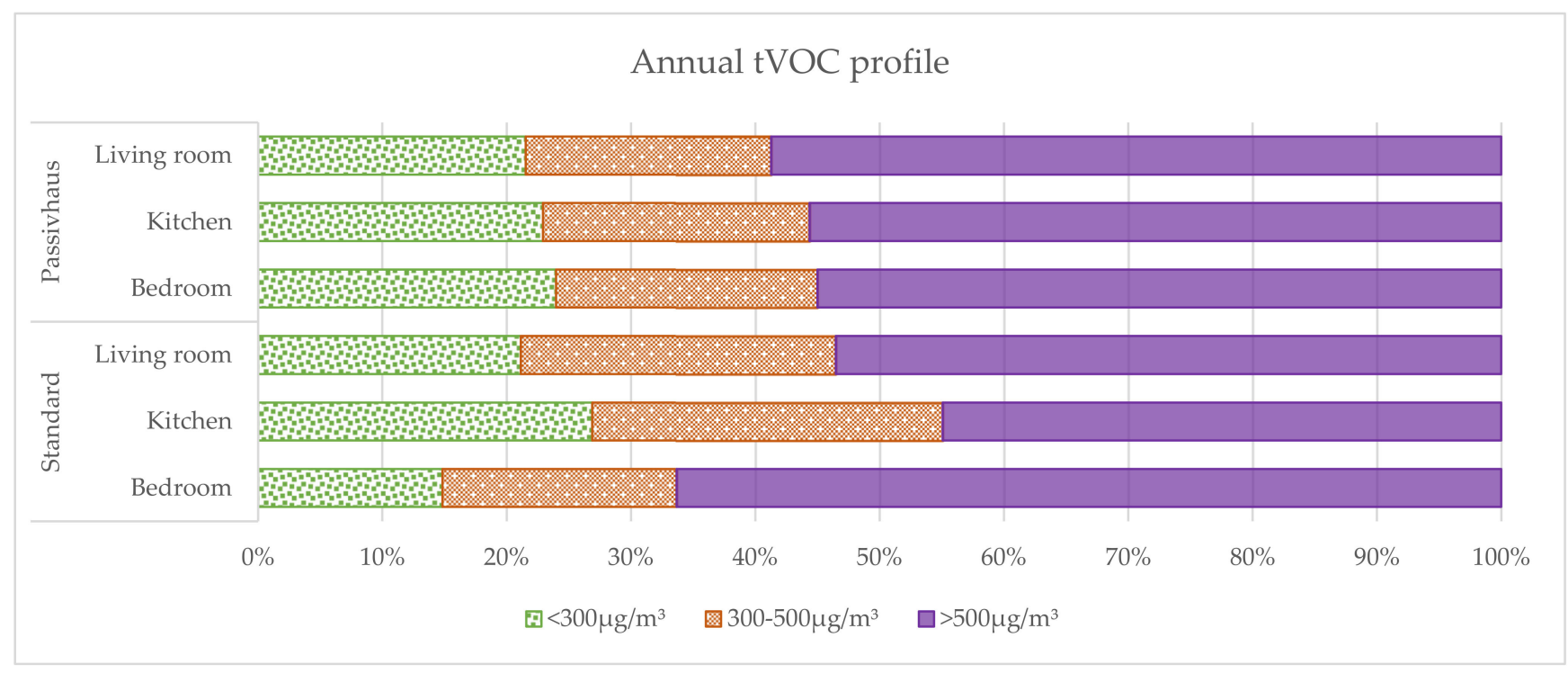

Figure 7. Annual tVOC profile in the Passivhaus and Standard dwellings. Source: Authors.

\subsection{Indoor Air Quality Perception}

Table 5 shows a summary of the occupants' summer IAQ perceptions. The surveys suggest that the Passivhaus fresh-stuffy scale $(M=4.67)$ for the summer months was rated 
poorly. It showed that while occupants were satisfied overall with the IAQ conditions, they did not perceive the freshness of the air as an important factor. The survey analysis suggests that occupants from the standard home had a constant dissatisfaction $(\mathrm{M}=4.00)$ with the IAQ in their home, as participants perceived the air to be stale $(\mathrm{M}=4.67)$, draughty $(\mathrm{M}=5.67)$, and smelly $(\mathrm{M}=5.33)$.

Table 5. Statistical analysis of the IAQ perceptions during summer for both homes. Source: Authors.

\begin{tabular}{|c|c|c|c|c|c|c|c|c|c|}
\hline IAQ Perception & $\begin{array}{l}\text { Home } \\
\text { Type }\end{array}$ & Resident & Score & Mean & SD & Mean + SD & Mean - SD & Min & Max \\
\hline \multirow{6}{*}{ Fresh (1)-stuffy (7) scale } & \multirow{3}{*}{ Passivhaus } & $\mathrm{R} 1$ & 4 & \multirow{3}{*}{4.7} & \multirow{3}{*}{0.6} & \multirow{3}{*}{5.2} & \multirow{3}{*}{4.1} & \multirow{3}{*}{4} & \multirow{3}{*}{5} \\
\hline & & $\mathrm{R} 2$ & 5 & & & & & & \\
\hline & & $\mathrm{R} 3$ & 5 & & & & & & \\
\hline & \multirow{3}{*}{ Standard } & $\mathrm{R} 1$ & 3 & \multirow{3}{*}{3.0} & \multirow{3}{*}{0.0} & \multirow{3}{*}{3.0} & \multirow{3}{*}{3.0} & \multirow{3}{*}{3} & \multirow{3}{*}{3} \\
\hline & & $\mathrm{R} 2$ & 3 & & & & & & \\
\hline & & $\mathrm{R} 3$ & 3 & & & & & & \\
\hline \multirow{6}{*}{ Dry (1)-humid (7) scale } & \multirow{3}{*}{ Passivhaus } & $\mathrm{R} 1$ & 4 & \multirow{3}{*}{4.0} & \multirow{3}{*}{1.0} & \multirow{3}{*}{5.0} & \multirow{3}{*}{3.0} & \multirow{3}{*}{3} & \multirow{3}{*}{5} \\
\hline & & $\mathrm{R} 2$ & 5 & & & & & & \\
\hline & & R3 & 3 & & & & & & \\
\hline & \multirow{3}{*}{ Standard } & R1 & 4 & \multirow{3}{*}{4.7} & \multirow{3}{*}{0.6} & \multirow{3}{*}{5.2} & \multirow{3}{*}{4.1} & \multirow{3}{*}{4} & \\
\hline & & $\mathrm{R} 2$ & 5 & & & & & & 5 \\
\hline & & $\mathrm{R} 3$ & 5 & & & & & & \\
\hline & & $\mathrm{R} 1$ & 3 & & & & & & \\
\hline & Passivhaus & $\mathrm{R} 2$ & 4 & 3.3 & 0.6 & 3.9 & 2.8 & 3 & 4 \\
\hline Still (1)-draughty (7) scale & & $\mathrm{R} 3$ & 3 & & & & & & \\
\hline & & R1 & 5 & & & & & & \\
\hline & Standard & $\mathrm{R} 2$ & 6 & 4.7 & 0.6 & 6.2 & 5.1 & 5 & 6 \\
\hline & & $\mathrm{R} 3$ & 6 & & & & & & \\
\hline & & R1 & 1 & & & & & & \\
\hline & Passivhaus & $\mathrm{R} 2$ & 4 & 2.3 & 1.5 & 3.9 & 0.8 & 1 & 4 \\
\hline Odourless (1)-smelly (7) & & $\mathrm{R} 3$ & 2 & & & & & & \\
\hline scale & & R1 & 5 & & & & & & \\
\hline & Standard & $\mathrm{R} 2$ & 5 & 5.3 & 0.6 & 5.9 & 4.8 & 5 & 6 \\
\hline & & $\mathrm{R} 3$ & 6 & & & & & & \\
\hline & & $\mathrm{R} 1$ & 1 & & & & & & \\
\hline & Passivhaus & $\mathrm{R} 2$ & 1 & 1.3 & 0.6 & 1.9 & 0.8 & 1 & 2 \\
\hline $\begin{array}{l}\text { Satistactory overall } \\
\text { (1)-unsatisfactory overall }\end{array}$ & & $\mathrm{R} 3$ & 2 & & & & & & \\
\hline (7) scale & & $\mathrm{R} 1$ & 3 & & & & & & \\
\hline & Standard & $\mathrm{R} 2$ & 5 & 7.0 & 1.0 & 5.0 & 3.0 & 3 & 5 \\
\hline & & $\mathrm{R} 3$ & 4 & & & & & & \\
\hline
\end{tabular}

The analysis of the winter IAQ perception surveys suggests that Passivhaus occupants rated the air as stale $(M=3.33)$. However, they stated being $(M=1.3)$ satisfied overall with the IAQ. Occupants of the standard home stated the air was stale $(M=4.67)$, draughty $(M=2.33)$, and smelly $(M=5.00)$, rating all these scales poorly. This may have led the occupants to rate very poorly the overall IAQ perception $(\mathrm{M}=5.33)$, as shown in Table 6 .

Passivhaus occupants reported that they did not experience condensation on windows or doors. However, they had experienced odours coming from outdoors; this may be related to the lack of filters in the inlet. Nonetheless, participants rated the odour scale on the odourless side, suggesting that the odours were not uncomfortable. Occupants of the standard home reported condensation on windows and the presence of mould in the bathroom. They also perceived smells coming from the kitchen, toilets, laundry closet, and outdoors. A possible explanation for the indoor odours could be that the windows remain closed for prolonged periods, causing the air to be stale and stuffy, as stated in the survey scale ratings. 
Table 6. Statistical analysis of the IAQ perceptions during winter for both homes. Source: Authors.

\begin{tabular}{|c|c|c|c|c|c|c|c|c|c|}
\hline IAQ Perception & $\begin{array}{l}\text { Home } \\
\text { Type }\end{array}$ & Resident & Score & Mean & SD & Mean + SD & Mean - SD & Min & Max \\
\hline \multirow{6}{*}{ Fresh (1)-stuffy (7) scale } & \multirow{3}{*}{ Passivhaus } & $\mathrm{R} 1$ & 4 & \multirow{3}{*}{3.3} & \multirow{3}{*}{1.2} & \multirow{3}{*}{4.5} & \multirow{3}{*}{2.2} & \multirow{3}{*}{2} & \multirow{3}{*}{4} \\
\hline & & $\mathrm{R} 2$ & 4 & & & & & & \\
\hline & & $\mathrm{R} 3$ & 2 & & & & & & \\
\hline & \multirow{3}{*}{ Standard } & $\mathrm{R} 1$ & 5 & \multirow{3}{*}{4.7} & \multirow{3}{*}{0.6} & \multirow{3}{*}{5.2} & \multirow{3}{*}{4.1} & \multirow{3}{*}{4} & \multirow{3}{*}{5} \\
\hline & & $\mathrm{R} 2$ & 5 & & & & & & \\
\hline & & $\mathrm{R} 3$ & 4 & & & & & & \\
\hline \multirow{6}{*}{ Dry (1)-humid (7) scale } & \multirow{3}{*}{ Passivhaus } & R1 & 3 & \multirow{3}{*}{4.0} & \multirow{3}{*}{1.0} & \multirow{3}{*}{5.0} & \multirow{3}{*}{3.0} & \multirow{3}{*}{3} & \multirow{3}{*}{5} \\
\hline & & $\mathrm{R} 2$ & 4 & & & & & & \\
\hline & & $\mathrm{R} 3$ & 5 & & & & & & \\
\hline & \multirow{3}{*}{ Standard } & R1 & 3 & \multirow{3}{*}{3.3} & \multirow{3}{*}{0.6} & \multirow{3}{*}{3.9} & \multirow{3}{*}{2.8} & \multirow{3}{*}{3} & \\
\hline & & $\mathrm{R} 2$ & 4 & & & & & & 4 \\
\hline & & $\mathrm{R} 3$ & 3 & & & & & & \\
\hline & & $\mathrm{R} 1$ & 4 & & & & & & \\
\hline & Passivhaus & $\mathrm{R} 2$ & 4 & 3.7 & 0.6 & 4.2 & 3.1 & 3 & 4 \\
\hline Still (1)-draughty (7) scale & & R3 & 3 & & & & & & \\
\hline & & $\mathrm{R} 1$ & 2 & & & & & & \\
\hline & Standard & $\mathrm{R} 2$ & 3 & 2.3 & 0.6 & 2.9 & 1.8 & 2 & 3 \\
\hline & & R3 & 2 & & & & & & \\
\hline & & $\mathrm{R} 1$ & 1 & & & & & & \\
\hline & Passivhaus & $\mathrm{R} 2$ & 4 & 2.7 & 1.5 & 4.2 & 1.1 & 1 & 4 \\
\hline Odourless (1)-smelly (7) & & R3 & 3 & & & & & & \\
\hline scale & & R1 & 5 & & & & & & \\
\hline & Standard & $\mathrm{R} 2$ & 5 & 5.0 & 0.0 & 5.0 & 5.0 & 5 & 5 \\
\hline & & $\mathrm{R} 3$ & 5 & & & & & & \\
\hline & & R1 & 1 & & & & & & \\
\hline & Passivhaus & $\mathrm{R} 2$ & 1 & 1.3 & 0.6 & 1.9 & 0.8 & 1 & 2 \\
\hline $\begin{array}{l}\text { Satisfactory overall } \\
\text { (1)-unsatisfactory overall }\end{array}$ & & R3 & 2 & & & & & & \\
\hline (7) scale & & R1 & 5 & & & & & & \\
\hline & Standard & $\mathrm{R} 2$ & 6 & 5.3 & 0.6 & 5.9 & 4.8 & 5 & 6 \\
\hline & & $\mathrm{R} 3$ & 5 & & & & & & \\
\hline
\end{tabular}

\section{Discussion}

This work presents long-term indoor air quality measurements conducted alongside airflow testing of the first residential Passivhaus building in Latin America. The results suggest that, in big cities in Latin America, dwellings built to the Passivhaus standard have the potential to achieve better IAQ compared to standard dwellings. This is of particular interest, as outdoor pollution in these cities usually exceeds the recommended levels of exposure [68]. Through this study, several lessons were learned that could help to develop further the Passivhaus standard in warm/temperate climates, such as the one in Mexico City.

The approach to the ventilation system may be the most important of these lessons. While the Passive House Institute would still recommend a MVHR in these climates, this study shows that hybrid ventilation may still be a viable option. However, the mechanical component of the ventilation method still needs to provide minimum airflow rates. It is recommended to use adequate filters, to ensure the best IAQ performance. It is also recommended to provide continuous, rather than intermittent, ventilation.

The levels of indoor air pollutants at the Passivhaus dwelling were lower than those in the standard home. However, pollution peaks took longer to dissipate in the Passivhaus home. This could have been related to the fact that the standard home relied on natural ventilation. Higher airflows helped to dissipate the air pollutants. Another potential 
explanation is related to the fact that the mechanical ventilation was not continuous (34 min on-26 min off). If a pollution event occurred during or close to when the fan was off, indoor air pollutants were not removed through ventilation. Similarly, indoor air pollutants, particularly tVOCs (Figure S3), in the standard home were higher during the night, when the windows were closed.

The $\mathrm{PM}_{2.5}$ and $\mathrm{tVOC}$ decay rates were lower in the Passivhaus dwelling compared to the standard dwelling, particularly those related to fine particles after cooking. The $\mathrm{PM}_{2.5}$ pollution decay in the Passivhaus $\left(1.1 \mathrm{~h}^{-1}\right)$ was longer compared to the conventional home $\left(0.24 \mathrm{~h}^{-1}\right)$ [69]. Similar to this study, a spike of $\mathrm{PM}_{2.5}$ was measured immediately after cooking events, but levels dropped quickly and then the peak concentrations began to decay gradually. In this study, a higher stability of $\mathrm{PM}_{2.5}$ levels across the different rooms was noted in the Passivhaus homes. This indicates the likely transport of particles from the source room to others, assisted by longer decay rates and doors opening/closing between spaces, facilitating further distribution of $\mathrm{PM}_{2.5}$.

Filters with $\mathrm{F} 7$ or higher levels of filtration are designed to filter $\mathrm{PM}_{2.5}$ and are recommended for Passivhaus. However, their use could lead to higher fan demands, noise, filter costs, maintenance, and even energy penalties. Ventilation rates and particle sedimentation primarily influence $\mathrm{PM}_{2.5}$ decay rate, whereas tVOC may also depend on operative room temperature and relative humidity. However, proper ventilation remains the best way to control indoor pollution. In this study, it was observed that window opening behaviour was the most effective technique to control indoor pollution.

Further works should test at larger scale the indoor air quality alongside thermal comfort and energy performance in other Passivhaus dwellings in Latin America. Such a study could support the positive impact on the Sustainable Development Goals 03 (health and wellbeing), 07 (affordable and clean energy), and 09 (industry, innovation, and infrastructure) for Latin American countries.

This study suffered from some apparent limitations. First of all, this work presents the monitoring results of two homes that are different in typology. As the standard dwelling was a typical representation of the housing typologies in Mexico City, it was deemed appropriate for comparison. In addition, it was not possible to find another dwelling of a similar layout within an appropriate radius from the Passivhaus, so that the outdoor air pollution was similar between both dwellings. In addition, at the time of this research, there was no other Passivhaus dwellings in Latin America to conduct the study. Second, the use of low-cost monitors could represent a compromise in accuracy. In order to overcome this barrier, we installed three different monitors in each room, developed calibration equations, and tested the accuracy of the monitors in real-life settings, as suggested by $[53,55]$. Third, the long-term (one year) coverage of this study made it difficult and too onerous for the participants to keep detailed activity and occupancy diaries. Therefore, the analysis was based on a general pattern. We also considered using other low-cost sensors to monitor the door/window use, but this was not economically feasible at the time of this study. Having data on the window opening could have allowed a better data analysis, but this was not feasible in this study. Finally, difference in the monitoring technologies between the indoor and outdoor air pollution sensors could represent minimal discrepancies between the readings.

\section{Conclusions}

This work presented the IAQ monitoring of the first Passivhaus residential dwelling in Latin America. The measurements demonstrate that the Passivhaus $\mathrm{CO}_{2}$ and $\mathrm{tVOC}$ annual average levels were $143.8 \mathrm{ppm}$ and $81.47 \mu \mathrm{g} / \mathrm{m}^{3}$ lower than the standard home. $\mathrm{PM}_{2.5}$ levels in the Passivhaus were $11.13 \mu \mathrm{g} / \mathrm{m}^{3}$ lower than the standard home and $5.75 \mu \mathrm{g} / \mathrm{m}^{3}$ lower than those outdoors. While these results give insights into the trends and relative levels air pollution, some lessons were also learned for the development of the Passivhaus in Latin America. It is possible to use a hybrid ventilation strategy to provide adequate ventilation in Passivhaus dwellings. While the use of MVHR units could be dependent 
on outdoor weather conditions, it is still preferable to use them, particularly in cities with high outdoor pollution. The ventilation strategy, independent of the use of the MVHR unit, needs to run continuously to provide adequate airflow levels and, hence, adequate indoor air pollution removal.

While the results presented here cannot be generalised, the results suggest that Passivhaus dwellings have the potential to provide better and healthier indoor air quality in Latin America. Further large-scale studies should consider the indoor environmental conditions, energy performance, and dwelling design of Passivhaus dwellings in Latin America.

Supplementary Materials: The following are available online at https: / www.mdpi.com/article/ 10.3390 /atmos12111477/s1, Table S1. Summary of CO2 levels in both homes; Figure S1. Standard home PM2.5 profile 29-30 June 2016; Figure S2. Passivhaus home PM2.5 profile 20-21 December 2016, Table S2. Summary of PM2.5 levels in both homes; Table S3. Summary of tVOC levels in both homes; Figure S3. Hourly tVOC levels in the Passivhaus and Standard dwelling's bedrooms.

Author Contributions: Conceptualisation: T.S., F.M., G.M., A.M.-R.; Methodology: T.S., F.M., G.M., A.M.-R.; Formal analysis: A.M.-R.; Investigation: A.M.-R.; Data Curation: A.M.-R.; Writing-Original Draft: A.M.-R.; Writing—Review \& Editing: T.S., F.M., G.M.; Visualisation: A.M.-R.; Supervision: T.S., F.M., G.M.; Project administration: T.S., F.M., G.M., A.M.-R.; Funding acquisition: A.M.-R. All authors have read and agreed to the published version of the manuscript.

Funding: CONACyT partially funded this research through a PhD grant. AirBoxLab (Foobot) partially funded this study, offering a discount on the monitors used in this research. The development of this article was supported by the Research England Expanding, Excellence in England (E3).

Institutional Review Board Statement: Ethical approval was sought and granted by the Glasgow School of Art Ethics Sub-committee; for further details, please refer to: https:/ /www.gsa.ac.uk/ media/497492/gsa_research_ethics_policy.pdf (accessed on 17 July 2019).

Informed Consent Statement: Informed consent was obtained from all subjects involved in the study.

Data Availability Statement: The data for this study were part of a $\mathrm{PhD}$ published in 2019 [55] with an embargo until March 2024. Data could be made available upon request from the corresponding author.

Acknowledgments: This work would not have been possible without the support of INHAB and the participation of the building occupants, to which we are thankful. Thanks are given to Adam Hotson, who offered useful editing and proofreading of an earlier version of this paper. The work published here was undertaken at the Mackintosh Environmental Research Unit.

Conflicts of Interest: None of the authors of this paper has a financial or personal relationship with other people or organisations that could inappropriately influence or bias the content of this article. The authors declare no conflict of interest.

\section{References}

1. Hopfe, C.J.; McLeod, R.S. The PassivHaus Designer's Manual: A Technical Guide to Low and Zero Energy Buildings, 1st ed.; Routledge: London, UK, 2015.

2. Sadineni, S.B.; Madala, S.; Boehm, R.F. Passive building energy savings: A review of building envelope components. Renew. Sustain. Energy Rev. 2011, 15, 3617-3631. [CrossRef]

3. Peters, T.; Halleran, A. How our homes impact our health: Using a COVID-19 informed approach to examine urban apartment housing. Int. J. Arch. Res. 2020, 15, 10-27. [CrossRef]

4. Al Khateeb, M.; Peterson, H. The impact of COVID-19 on perceptions of home and house design in Saudi Arabia. Strat. Des. Res. J. 2021, 14, 327-338. [CrossRef]

5. Passive House Institute. Passipedia. 2017. Available online: http://www.passipedia.org/ (accessed on 3 May 2021).

6. Moreno-Rangel, A. Passivhaus. Encyclopedia 2020, 1, 20-29. [CrossRef]

7. Feist, W.; Bastian, Z.; Ebel, W.; Gollwitzer, E.; Grove-Smith, J.; Kah, O.; Kaufmann, B.; Krick, B.; Pfluger, R.; Schnieders, J.; et al. Passive House Planning Package Version 9: The Energy Balance and Design Tool for Efficent Buildings and Retrofits, 1st ed.; Passive House Institute: Darmstadt, Germany, 2015.

8. Costanzo, V.; Carrillo Gómez, J.E.; Evola, G.; Marletta, L. Suitability of Passivhaus design for housing projects in Colombia. In Sustainability in Energy and Buildings; Littlewood, J., Howlett, R.J., Capozzoli, A., Jain, L.C., Eds.; Smart Innovation, Systems and Technologies; Springer: Singapore, 2020; Volume 163, pp. 97-107. 
9. Valiente, E.E.; Garcia-Alvarado, R.; Celis-D’Amico, F.; Saelzer-Fuica, G. Integrated design experiences for energy-efficient housing in Chile. Constr. Innov. 2019, 19, 236-255. [CrossRef]

10. Vettorazzi, E.; Figueiredo, A.; Rebelo, F.; Vicente, R.; da Cunha, E.G. Optimization of the passive house concept for residential buildings in the South-Brazilian region. Energy Build. 2021, 240, 110871. [CrossRef]

11. Gesellschaft für Internationale Zusammenarbeit. NAMA Facility-Implementation of the New Housing NAMA Mexico. 2014. Available online: http:/ / www.nama-facility.org/projects/mexico.html (accessed on 20 May 2009).

12. Feist, W. Technical Annex: Evaluation of Social Housing Building Types in Mexico. In Supported NAMA for Sustainable Housing in Mexico: Mitigation Actions and Finance; Mexico's National Housing Commission: Mexico City, Mexico, 2012.

13. Bravo-Orlandini, C.; Gómez-Soberón, J.; Valderrama-Ulloa, C.; Sanhueza-Durán, F. Energy, Economic, and Environmental Performance of a Single-Family House in Chile Built to Passivhaus Standard. Sustainability 2021, 13, 1199. [CrossRef]

14. Carrasco, J.; Kokogiannakis, G. Feasibility of PassivHaus standards and alternative passive design on climatic zones of ChileDetermination of energy requirements with dynamic simulation. Hábitat Susten. 2012, 2, 59-71.

15. Cruz, A.S.; de Carvalho, R.S.; da Cunha, E.G. Passive House Alternative Proposal for the Brazilian Bioclimatic Zone 8. Int. J. Sustain. Dev. Plan. 2020, 15, 827-833. [CrossRef]

16. Moreno-Rangel, A.; Sharpe, T.; McGill, G.; Musau, F. Thermal comfort assessment of the first residential Passivhaus in Latin America. J. Build. Eng. 2021, 43, 103081. [CrossRef]

17. Schnieders, J.; Eian, T.D.; Filippi, M.; Florez, J.; Kaufmann, B.; Pallantzas, S.; Paulsen, M.; Reyes, E.; Wassouf, M.; Yeh, S.-C. Design and realisation of the Passive House concept in different climate zones. Energy Effic. 2019, 13, 1561-1604. [CrossRef]

18. Moreno-Rangel, A.; Sharpe, T.; Musau, F.; McGill, G. Indoor Fine Particle $\left(\mathrm{PM}_{2.5}\right)$ Pollution and Occupant Perception of the Indoor Environment During Summer of the First Passivhaus Certified Dwelling in Latin America. J. Nat. Resour. Dev. 2018, 8, 78-90. [CrossRef]

19. Ridley, I.A.; Bere, J.; Clarke, A.; Schwartz, Y.; Farr, A. The side by side in use monitored performance of two passive and low carbon Welsh houses. Energy Build. 2014, 82, 13-26. [CrossRef]

20. Colclough, S.; Kinnane, O.; Hewitt, N.; Griffiths, P. Investigation of nZEB social housing built to the Passive House standard. Energy Build. 2018, 179, 344-359. [CrossRef]

21. Wang, Y.; Kuckelkorn, J.; Zhao, F.-Y.; Spliethoff, H.; Lang, W. A state of art of review on interactions between energy performance and indoor environment quality in Passive House buildings. Renew. Sustain. Energy Rev. 2017, 72, 1303-1319. [CrossRef]

22. Foster, J.; Sharpe, T.; Poston, A.; Morgan, C.; Musau, F. Scottish Passive House: Insights into Environmental Conditions in Monitored Passive Houses. Sustainability 2016, 8, 412. [CrossRef]

23. Grudzińska, M. Overheating assessment in flats with glazed balconies in warm-summer humid continental climate. Build. Serv. Eng. Res. Technol. 2021, 42, 583-602. [CrossRef]

24. Fletcher, M.; Johnston, D.; Glew, D.; Parker, J. An empirical evaluation of temporal overheating in an assisted living Passivhaus dwelling in the UK. Build. Environ. 2017, 121, 106-118. [CrossRef]

25. Finegan, E.; Kelly, G.; O'Sullivan, G. Comparative analysis of Passivhaus simulated and measured overheating frequency in a typical dwelling in Ireland. Build. Res. Inf. 2019, 48, 681-699. [CrossRef]

26. Moreno-Rangel, A.; Sharpe, T.; McGill, G.; Musau, F. Indoor Air Quality in Passivhaus Dwellings: A Literature Review. Int. J. Environ. Res. Public Health 2020, 17, 4749. [CrossRef]

27. Derbez, M.; Berthineau, B.; Cochet, V.; Lethrosne, M.; Pignon, C.; Riberon, J.; Kirchner, S. Indoor air quality and comfort in seven newly built, energy-efficient houses in France. Build. Environ. 2014, 72, 173-187. [CrossRef]

28. Feist, W.; Pfluger, R.; Hasper, W. Durability of building fabric components and ventilation systems in passive houses. Energy Effic. 2019, 13, 1543-1559. [CrossRef]

29. Wang, Z.; Xue, Q.; Ji, Y.; Yu, Z. Indoor environment quality in a low-energy residential building in winter in Harbin. Build. Environ. 2018, 135, 194-201. [CrossRef]

30. Jacobs, D.E.; Kelly, T.; Sobolewski, J. Linking Public Health, Housing, and Indoor Environmental Policy: Successes and Challenges at Local and Federal Agencies in the United States. Environ. Heal. Perspect. 2007, 115, 976-982. [CrossRef]

31. Rosseau, D.; Bowser, D.; Mattock, C. A Guide to Mechanical Equipment for Healthy Indoor Environments. 2001. Available online: https:/ / www.cmhc-schl.gc.ca/odpub/pdf/62015.pdf (accessed on 7 November 2018).

32. American Society of Heating, Refrigerating and Air-Conditioning Engineers. ASHRAE Standard 62.1-2007 Ventilation for Acceptable Indoor Air Quality; American Society of Heating, Refrigerating and Air-Conditioning Engineers: Atlanta, GA, USA, 2007.

33. World Health Organization. Air Quality Guidelines for Europe, 2nd ed.; WHO Regional Publications: Copenhagen, Denmark, 2000.

34. World Health Organization. WHO Guidelines for Indoor Air Quality: Selected Pollutants, 1st ed.; World Health Organization Regional Office for Europe: Copenhagen, Denmark, 2010; Volume 9.

35. Dan, D.; Tanasa, C.; Stoian, V.; Brata, S.; Stoian, D.; Gyorgy, T.N.; Florut, S. Passive house design-An efficient solution for residential buildings in Romania. Energy Sustain. Dev. 2016, 32, 99-109. [CrossRef]

36. Fokaides, P.A.; Christoforou, E.; Ilic, M.; Papadopoulos, A. Performance of a Passive House under subtropical climatic conditions. Energy Build. 2016, 133, 14-31. [CrossRef]

37. Santin, O.G.; Grave, A.; Jiang, S.; Tweed, C.; Mohammadi, M. Monitoring the performance of a Passivhaus care home: Lessons for user-centric design. J. Build. Eng. 2021, 43, 102565. [CrossRef] 
38. Kaunelienė, V.; Prasauskas, T.; Krugly, E.; Stasiulaitienė, I.; Čiužas, D.; Šeduikytė, L.; Martuzevicius, D. Indoor air quality in low energy residential buildings in Lithuania. Build. Environ. 2016, 108, 63-72. [CrossRef]

39. Less, B.; Mullen, N.; Singer, B.; Walker, I. Indoor air quality in 24 California residences designed as high-performance homes. Sci. Technol. Built Environ. 2015, 21, 14-24. [CrossRef]

40. Guillén-Lambea, S.; Soria, B.R.; Marín, J.M. Review of European ventilation strategies to meet the cooling and heating demands of nearly zero energy buildings (nZEB)/Passivhaus. Comparison with the USA. Renew. Sustain. Energy Rev. 2016, 62, 561-574. [CrossRef]

41. Langer, S.; Bekö, G.; Bloom, E.; Widheden, A.; Ekberg, L. Indoor air quality in passive and conventional new houses in Sweden. Build. Environ. 2015, 93, 92-100. [CrossRef]

42. Wallner, P.; Tappler, P.; Munoz, U.; Damberger, B.; Wanka, A.; Kundi, M.; Hutter, H.-P. Health and Wellbeing of Occupants in Highly Energy Efficient Buildings: A Field Study. Int. J. Environ. Res. Public Health 2017, 14, 314. [CrossRef]

43. Meyer, W. Impact of constructional energy-saving measures on radon levels indoors. Indoor Air 2019, 29, 680-685. [CrossRef]

44. Lim, A.-Y.; Yoon, M.; Kim, E.-H.; Kim, H.-A.; Lee, M.J.; Cheong, H.-K. Effects of mechanical ventilation on indoor air quality and occupant health status in energy-efficient homes: A longitudinal field study. Sci. Total. Environ. 2021, 785, 147324. [CrossRef]

45. Langer, S.; Ramalho, O.; Derbez, M.; Ribéron, J.; Kirchner, S.; Mandin, C. Indoor environmental quality in French dwellings and building characteristics. Atmos. Environ. 2016, 128, 82-91. [CrossRef]

46. McGill, G.; Oyedele, L.O.; Keeffe, G. Indoor air-quality investigation in code for sustainable homes and passivhaus dwellings. World J. Sci. Technol. Sustain. Dev. 2015, 12, 39-60. [CrossRef]

47. Wilson, J.; Dixon, S.L.; Jacobs, D.E.; Breysse, J.; Akoto, J.; Tohn, E.; Isaacson, M.; Evens, A.; Hernandez, Y. Watts-to-Wellbeing: Does residential energy conservation improve health? Energy Effic. 2013, 7, 151-160. [CrossRef]

48. Milner, J.; Shrubsole, C.; Das, P.; Jones, B.; Ridley, I.A.; Chalabi, Z.; Hamilton, I.; Armstrong, B.; Davies, M.; Wilkinson, P. Home energy efficiency and radon related risk of lung cancer: Modelling study. BMJ 2013, 348, f7493. [CrossRef] [PubMed]

49. McGill, G.; Sharpe, T.; Oyedele, L.; Keeffe, G.; McAllister, K. An investigation of indoor air quality in UK Passivhaus dwellings. In Smart Energy Control Systems for Sustainable Buildings; Smart Innovation, Systems and Technologies; 2017; Volume 67, pp. 245-268. [CrossRef]

50. Sherman, M.H.; Chan, R. Building Airtightness: Research and Practice; Lawrence Berkeley National Laboratory Report No. LBNL53356; Lawrence Berkeley National Laboratory: Berkeley, CA, USA, 2004.

51. Seppänen, O.; Fisk, W.J. Association of ventilation system type with SBS symptoms in office workers. Indoor Air 2002, 12, 98-112. [CrossRef]

52. Kottek, M.; Grieser, J.; Beck, C.; Rudolf, B.; Rubel, F. World Map of the Köppen-Geiger climate classification updated. Meteorol. Z. 2006, 15, 259-263. [CrossRef]

53. Moreno-Rangel, A.; Sharpe, T.; Musau, F.; McGill, G. Field evaluation of a low-cost indoor air quality monitor to quantify exposure to pollutants in residential environments. J. Sensors Sens. Syst. 2018, 7, 373-388. [CrossRef]

54. Petersen, J.; Kristensen, J.; Elarga, H.; Andersen, R.; Midtstraum, A. Accuracy and Air Temperature Dependency of Commercial Low-Cost NDIR $\mathrm{CO}_{2}$ Sensors: An Experimental Investigation. In Proceedings of the 4th International Conference on Building Energy \& Environment, Melbourne, VIC, Australia, 5-9 February 2018; pp. 203-207.

55. Moreno-Rangel, A. Continuous IAQ Monitoring with Low-Cost Monitors: Protocol Development, Performance and Application in Residential Building. Ph.D. Thesis, The Glasgow School of Art, Glasgow, Scotland, April 2019.

56. Raw, G.J. A Questionnaire for Studies of Sick Building Syndrome; A Report to the Royal Society of Health; BRE Press: Watford, ND, USA, 1995.

57. European Committee for Standardization. Indoor Environmental Input Parameters for Design and Assessment of Energy Performance of Buildings Addressing Indoor Air Quality, Thermal Environment, Lighting and Acoustics; EN 15251:2007; European Committee for Standardization: Brussels, Belgium, 2008.

58. Chartered Institution of Building Services Engineers. CIBSE Guide A: Environmental Design, 7th ed.; CIBSE Publications: Norwich, UK, 2006.

59. Mendez Florian, F.; Velasco Sodi, P. Estrategia Nacional para la Vivienda Sustentable; Componente Ambiental de la Sustentabilidad; Fundacion IDEA: Mexico City, Mexico, 2013.

60. Wargocki, P. The Effects of Ventilation in Homes on Health. Int. J. Vent. 2013, 12, 101-118. [CrossRef]

61. Engineering ToolBox. Carbon Dioxide Concentrations in Rooms with People. 2004. Available online: https://www. engineeringtoolbox.com/pollution-concentration-rooms-d_692.html (accessed on 23 May 2018).

62. European Committee for Standardization. Ventilation for Non-Residential Buildings_Performance Requirements for Ventilation and Room-Conditioning Systems; EN 13779:2007; European Committee for Standardization: Brussels, Belgium, 2007.

63. Barraza-Villarreal, A.; Sunyer, J.; Cadena, L.H.; Escamilla-Nuñez, M.C.; Sienra-Monge, J.J.; Ramírez-Aguilar, M.; Cortez-Lugo, M.; Holguin, F.; Diaz-Sanchez, D.; Olin, A.C.; et al. Air Pollution, Airway Inflammation, and Lung Function in a Cohort Study of Mexico City Schoolchildren. Environ. Health Perspect. 2008, 116, 832-838. [CrossRef]

64. Holguín, F.; Téllez-Rojo, M.M.; Hernández, M.; Cortez, M.; Chow, J.C.; Watson, J.G.; Mannino, D.; Romieu, I. Air Pollution and Heart Rate Variability Among the Elderly in Mexico City. Epidemiology 2003, 14, 521-527. [CrossRef] 
65. Cortez-Lugo, M.; Moreno-Macias, H.; Holguin-Molina, F.; Chow, J.C.; Watson, J.G.; Gutiérrez-Avedoy, V.; Mandujano, F.; Hernández-Ávila, M.; Romieu, I. Relationship between indoor, outdoor, and personal fine particle concentrations for individuals with COPD and predictors of indoor-outdoor ratio in Mexico City. J. Expo. Sci. Environ. Epidemiol. 2007, 18, 109-115. [CrossRef]

66. Sosa, E.R.; Bravo, A.H.; Mugica-Alvarez, V.; Sanchez, A.P.; Bueno, L.E.; Krupa, S. Levels and source apportionment of volatile organic compounds in southwestern area of Mexico City. Environ. Pollut. 2009, 157, 1038-1044. [CrossRef] [PubMed]

67. Holøs, S.B.; Yang, A.; Lind, M.; Thunshelle, K.; Schild, P.; Mysen, M. VOC emission rates in newly built and renovated buildings, and the influence of ventilation-A review and meta-analysis. Int. J. Vent. 2018, 18, 153-166. [CrossRef]

68. Bell, M.L.; Davis, D.L.; Gouveia, N.; Borja-Aburto, V.H.; Cifuentes, L.A. The avoidable health effects of air pollution in three Latin American cities: Santiago, São Paulo, and Mexico City. Environ. Res. 2006, 100, 431-440. [CrossRef] [PubMed]

69. Militello-Hourigan, R.E.; Miller, S.L. The impacts of cooking and an assessment of indoor air quality in Colorado passive and tightly constructed homes. Build. Environ. 2018, 144, 573-582. [CrossRef] 